\title{
THE EFFECT OF PROBIOTIC IN MILK FERMENTATION TOWARDS DECREASING CHOLESTEROL LEVELS: IN VIVO STUDIES
}

\author{
Ria Dewi Andriani*1), Premy Puspitawati Rahayu ${ }^{1)}$, and Mulia Winirsya Apriliyani ${ }^{1)}$ \\ 1) Animal Product Technology Department, Faculty of Animal Science, \\ Universitas Brawijaya Jl. Veteran, Malang, 65145, East Java, Indonesia \\ E-mail: riaandriani@ub.ac.id
}

Submitted 23 September 2019; Accepted 6 February 2020

\begin{abstract}
Hypercholesterolemia is a disease that is indicated by the increasing level of cholesterol in the body and also as one of the factors causing cardiovascular disease. An alternative that can be done to prevent hypercholesterolemia is by consuming fermented milk. Skim milk is fermented using probiotic of Lactobacillus acidophillus, Lactobacillus plantarum and Streptococcus thermophilus. The skimmed milk that has been fermented is then tested for total lactic acid bacteria, total acid, $\mathrm{pH}$, and in vivo analysis for antihypercholesterolemia activity using animal model. In this study, the animal models used were male white rats which were grouped into three treatment groups, namely negative control, positive control, and fermented milk group. The result of the study shows that the total lactic acid bacteria, total acid and $\mathrm{pH}$ of fermented skim milk were $5.25 \times 10^{9} \mathrm{CFU} / \mathrm{mL} ; 2.190 \%$ and $\mathrm{pH} 4.06$, respectively. From the results, fermented milk with probiotics has the ability to reduce cholesterol levels in the blood of male white rats effectively in vivo.
\end{abstract}

Keywords: Probiotic; milk fermentation; antihypercholesterolemia 


\section{INTRODUCTION}

Cholesterol is a type of fat which functions as a cell protector, help produce vitamin $\mathrm{D}$, and form steroid hormones (Wang et al., 2018). Excess cholesterol in the blood can cause hypercholesterolemia which is a condition when the level of cholesterol in the blood exceeds the normal limit of $200 \mathrm{mg} / \mathrm{dl}$. One of the triggers for hypercholesterolemia is lifestyle changes and unhealthy eating patterns, such as highfat food consumption. Excess cholesterol in the blood will cause cardiovascular disease and stroke (Dokic et al., 2015). The World Health Organization (WHO) in 2017 reported that cardiovascular disease is the world's first leading cause of death (Depkes RI, 2017).

Hypercholesterolemia can be treated in various ways. One of the safest alternatives is to change lifestyle by consuming functional foods that are able to control the amount of cholesterol in the blood, such as probiotic drinks. Probiotics are drinks containing probiotic bacteria which has health effects due to the fermentation process. Probiotics can be used as antihypercholesterolemia therapy since probiotic bacteria can increase the secretion of Bile Salt Hydrolase (BSH) enzyme which then enable the increasing excretion of bile acids (Naim, 2011; Gulzar et al., 2019). Apart from that, probiotic bacteria produce cholesterol dehydrogenase cofactor which functions to activate the cholesterol reductase enzyme, converting cholesterol into cosprotanol.

Cosprotanol is a sterol that cannot be absorbed by the intestine, therefore it is released through feces enabling cholesterol to go down. Several studies have shown that lactic acid bacteria can reduce cholesterol in

*Corresponding author:

Ria Dewi Andriani

Email: riaandriani@ub.ac.id

Animal Product Technology Department, Faculty of Animal Science, Universitas Brawijaya Jl. Veteran, Malang, 65145, East Java, Indonesia vitro and in vivo (Naim, 2011; Octavia et al., 2017; Wang et al., 2018). Cholesterol reduction is assumed to happen due to its ability to assimilate cholesterol in the small intestine and de-conjugate bile salts. The results of a study by Oktavia et al., (2017) reveals that yogurt with banana flour given to wistar rats proves to decrease in triglyceride levels, total cholesterol, LDL cholesterol, and an increase in HDL cholesterol. Ishmayana et al. (2015) conducted a study on the effect of yoghurt consumption made with two bacterial culture and three bacterial culture on rat blood serum cholesterol levels. The study obtained a result where yoghurt made with three bacteria (S. thermophillus, $L$. bulgaricus and L. acidophilus) showed a better effect on decreasing blood serum cholesterol levels compared to two bacteria yoghurts ( $S$. thermophillus and $L$. bulgaricus). Based on both studies above, therefore this study was done by using skim milk with the addition three combination of lactic acid bacteria probiotics and its activity as an antihypercholesterolemia in vivo. Skim milk contained 5\% lactose which the main carbohydrate in milk that can be used by bacteria starter as energy source for growth.

\section{MATERIAL AND METHODS}

The materials used in this study include skim milk, Lactobacillus plantarum, Lactobacillus acidophillus, Streptococcus thermophilus, deMann Rogosa Sharpe Broth (MRSB) (Oxoid, Ltd, England), Pepton (Oxoid, Ltd, UK), 70\% alcohol, and sterile aquades which were obtained from the Faculty of Medicine, Universitas Brawijaya. The rats (Rattus norvegivus) feed used was a modified AIN-93M standard feed. Male

How to cite:

Andriani, R. D., Rahayu, P. P., \& Apriliyani,M. W. (2020). The Effect of Probiotic in Milk Fermentation Towards Decreasing Cholesterol Levels: in Vivo Studies. Jurnal Ilmu dan Teknologi Hasil Ternak, 15 (1), 13-20 
wistar rats (Rattus norvegivus) were obtained from Malang Murine Farm which weighs between 180-200 $\mathrm{g}$ which were examined in the in vivo testing. The equipment used in the study was an incubator, autoclave, laminar, $\mathrm{pH}$ meter, cholesterol strip test, digital cholesterol check tool and mouse cages.

\section{Preparation for BAL Cultivation}

Lactobacillus plantarum, Lactobacillus acidophilus, and Streptococcus thermophilus in MRS agar slant were inoculated onto MRSB media and incubated at $37^{\circ} \mathrm{C}$ for 24 h. Subsequently, bacteria were centrifuged and poured into pasteurized skim milk and incubated at $37^{\circ} \mathrm{C}$ for $24 \mathrm{~h}$.

\section{Preparation of Fermented Milk}

Making fermented milk is done by pasteurizing skim milk at $85{ }^{\circ} \mathrm{C}$ for $15 \mathrm{~min}$, then lowering the temperature to $40^{\circ} \mathrm{C}$. Skim milk is then added to the LAB starter with a concentration of $2 \%(\mathrm{v} / \mathrm{v})$. The milk is then incubated for $16 \mathrm{~h}$ at $37{ }^{\circ} \mathrm{C}$. The fermented milk is then tested for its total lactic acid bacteria, total acid, $\mathrm{pH}$, and antihypercholesterolemia activity by using animal model.

\section{Total Lactic Acid Bacteria}

The total LAB measurement was based on Pelezar et al. (2007) method. A sample of $25 \mathrm{~mL}$ of fermented milk was dissolved in $225 \mathrm{~mL}$ of sterile pepton water and then homogenized, and $1\left(\mathrm{P}^{-1}\right)$ dilution was obtained. Furthermore, dilution $1\left(\mathrm{P}^{-1}\right)$ was taken as much as $1 \mathrm{~mL}$ and afterwards put in $9 \mathrm{~mL}$ of peptone water to obtain $\left(\mathrm{P}^{-2}\right)$ dilution. The dilution is carried out up to the $\mathrm{P}^{-9}$ dilution. From this dilution then $\mathrm{P}^{-6}$ to $\mathrm{P}^{-9}$ dilutions are taken to be inoculated on MRSA media by pour plate method and then incubated for $48 \mathrm{~h}$ and eventually calculated using the standard plate count method.

\section{Total Acid}

Total titrable acidity was carried out by taking a sample of $10 \mathrm{~mL}$ and then added with 3 drops of phenolphthalein indicator which was then titrated with $0.1 \mathrm{~N} \mathrm{NaOH}$ solution until the color turned pink and when homogenized the color does not disappear (Nielsen, 2003).

\section{pH}

Measurement of the $\mathrm{pH}$ value was done using a pH meter (AOAC, 2005) which was previously calibrated using a buffer of $\mathrm{pH} 4$ and $\mathrm{pH}$ 7. The measurement is done by dipping the $\mathrm{pH}$ meter electrode in $10 \mathrm{~mL}$ of fermented milk sample and waited until the number on the $\mathrm{pH}$ meter is stable.

\section{Antihypercholesterolemia Condition Testing}

The experimented animals used in this study were 18 male white wistar rats (Rattus norvegivus) weighing 180-200 g/rats. The experimented animals used were not defective and had never been used in other studies. The experimented animals were grouped into 3 treatment groups with each group consisting of 6 animals (Table 1).

Table 1. Experiment treatment groups used in the study

\begin{tabular}{ll}
\hline Groups & Treatment \\
\hline Negative Control (K1) & $\begin{array}{l}\text { Experimental animals were given standard AIN-93M } \\
\text { modified feed and egg yolk induction }\end{array}$ \\
Positive Control (K2) & $\begin{array}{l}\text { Experimental animals were given standard AIN-93M } \\
\text { modified feed, egg yolk induction, and simvastatin }\end{array}$ \\
Fermented Milk (K3) & $\begin{array}{l}\text { Experimental animals were given standard AIN-93M } \\
\text { modified feed, egg yolk induction, and fermented milk }\end{array}$ \\
\hline
\end{tabular}

The rats were acclimatized for one week before treatment with the aim to adapt laboratory conditions. To create cholesterol conditions the rats were induced with quail yolk up to hypercholesterol conditions. During the treatment the rats were given 
standard modified AIN-93M feed and drinking water ad libitum. The experiment was carried out for $21 \mathrm{~d}$ and each rat was measured for their cholesterol levels every $7 \mathrm{~d}$.

\section{Measurement of Blood Cholesterol on Animal Tested}

The sample of blood was taken through the rat's tail as much as $\pm 1 \mathrm{cc}$ using blood lancet. The blood sample was then dropped on a cholesterol kit and waited for $150 \mathrm{~s}$ and the sample cholesterol level was identified.

\section{RESULTS AND DISCUSSIONS}

The objective of this study is to discover whether fermented skim milk has antihypercholesterolemia activity on male white rats (Rattus novergicus). Firstly, the fermented milk is characterized to determine the total number of lactic acid bacteria, the total titrable acidity, and the $\mathrm{pH}$ value.

\section{Total Lactic Acid Bacteria}

Based on the results of the study, the average of total lactic acid bacteria produced in the fermented skim milk was $5.25 \times 10^{9} \mathrm{CFU} / \mathrm{mL}$. The total lactic acid bacteria were calculated using the standard plate count method. The number of these bacteria has met the standards for probiotic products with a minimum number of viable bacteria $10^{6}-10^{7} \mathrm{CFU} / \mathrm{mL}$ (Manea et al., 2010).

That number is the minimum number of cells that delivers health effects for human (Syachroni, 2014). The minimum amount of probiotic strains present in food products is $10^{6} \mathrm{CFU} / \mathrm{g}$ or the number of probiotic strains that must be consumed every day is approximately $10^{8} \mathrm{CFU} / \mathrm{g}$, with the aim to offset the possibility of a decrease in the number of probiotic bacteria while in the digestive system (Puryana, 2011).

The selection of probiotic bacteria must consider several aspects, especially safety and functional aspects. Safety aspects include, probiotic bacteria must maintain the digestive system healthy, non-pathogenic or safe for consumption and resistant to antibiotics. Functional aspects include the ability of living probiotic bacteria in the digestive system, resistant to acidic conditions in the stomach so that bacteria can multiply in the intestine, not cause a distorted aroma on the probiotic product made. In addition, probiotic strains must also be resistant and remain alive during product processing and storage (Puryana, 2011; Pisano et al., 2014).

\section{Total Titrable Acidity}

The results showed that the average total titrable acidity in fermented skimmed milk was $2.19 \%$. Septiani et al. (2013) revealed that the more bacteria produce lactic acid, the higher the acid formed. The acidity of yoghurt can be measured by titration. The acidity of fermented milk due to lactose breakdown by lactic acid bacteria. The total acid titrated in food is determined by acid-base titration which will estimate the total acid concentration.

Most of these acids are organic acids that affects taste, color, microbial stability and food quality (Sadler and Murphy, 2003). Total acid will increase during storage and the peak of its increase occurs in fermented milk using mixed starter cultures. The acidic sense in yoghurt is caused by lactose metabolism by lactic acid bacteria resulting an acidic taste and casein deposition (Sawitri et al., 2008).

\section{pH Value}

Based on the result the average $\mathrm{pH}$ value of fermented milk is 4.05 . The range of $\mathrm{pH}$ values correlates with the statement made by Farinde et al. (2010) which states that a good yoghurt probiotic drink has a $\mathrm{pH}$ value between 3.5-4.5. Sunarlim et al., (2007) also revealed that the lower $\mathrm{pH}$ value, the higher the amount of titrable acidity value. Bacterial activity can be seen through changes in $\mathrm{pH}$ and total titrated acid.

The longer incubation time for milk, the higher the total acid produced. This is caused by the increase of total acid 
alongside with the length of fermentation, allowing more time available for lactic acid bacteria to breakdown the nutrients contained in the substrate which eventually allow the accumulation of organic acids in higher amounts (Yunus and Zubaidah, 2015). Lactose in milk also has an important role in the growth of bacteria, because lactic acid bacteria survive from consuming lactose and produce lactic acid.

This acid also preserves milk and degrades lactose, enabling people who are intolerant of whole milk to consume fermented milk without getting health problems (Resnawati, 2010). The decrease in $\mathrm{pH}$ is a result of the fermentation process that occurs due to the accumulation of acids derived from lactic acid bacteria, meanwhile protein is used to spur the development of lactic acid bacteria, while lactose is used by starter bacteria as a carbon source and metabolism lactic acid is produced which will decrease of pH (Sintasari et al., 2014). The combination of starter Streptococcus thermophilus and Lactobacillus acidophillus can increase lactic acid and cause a decrease in the $\mathrm{pH}$ (Sunarlim et al., 2007). The decrease in $\mathrm{pH}$ is determined by the presence of $\mathrm{H}^{+}$ions, causing the $\mathrm{pH}$ to lower (Burton et al., 2014; Sunarlim et al., 2007)

\section{Antihypercholesterolemia Activity}

Based on Table 2, the average reduction percentage in cholesterol levels varies for each treatment group. It shows decrease in negative control cholesterol levels by $31.00 \mathrm{mg} / \mathrm{dL}$ positive control of $122.08 \mathrm{mg} / \mathrm{dl}$ fermented milk treatment of $169.54 \mathrm{mg} / \mathrm{dl}$, respectively.

Table 2. Data on the average test results of the cholesterol level on the test animals

\begin{tabular}{ccccc}
\hline \multirow{2}{*}{$\begin{array}{c}\text { Group } \\
\text { treatment }\end{array}$} & \multicolumn{2}{c}{ Average Cholesterol Level } & Average decrease in Cholesterol Level \\
\cline { 2 - 5 } & Start $(\mathrm{mg} / \mathrm{dL})$ & Final $(\mathrm{mg} / \mathrm{dL})$ & \multicolumn{1}{c}{$(\mathrm{mg} / \mathrm{dL})^{*}$} & $(\%)^{*}$ \\
\hline K1 & 248.05 & 217.05 & $31.00 \pm 7.70$ & 12.49 \\
K2 & 241.00 & 112.08 & $122.08 \pm 3.80$ & 49.34 \\
K3 & 254.21 & 169.54 & $169.54 \pm 7.11$ & 33.31 \\
\hline
\end{tabular}

The decrease in cholesterol levels that occurred in the positive control group was greater than the other groups. This is due to the simvastatin given which is an antihypercholesterolemia drug.

According to Harini (2009) the mechanism of simvastatin as an antihypercholesterolemia is by inhibiting 3hydroxy-3-methyl glutaryl Coenzyme A eductase (HMG CoA Reductase), which is an enzyme that catalyzes HMG Co-A into mevalonic acid. The way it works is to inhibit the formation of cholesterol in the liver and then increases the removal of LDL from the bloodstream. The inhibition of HMG-CoA reductase causes a decrease in cholesterol synthesis and increases the number of LDL receptors found in liver cell membranes, therefore the total cholesterol and LDL cholesterol levels in the plasma falls (Setiawan et al., 2016). The decrease in cholesterol levels in the fermented milk group was smaller than the positive control, however supplementation of fermented milk was proven to reduce high cholesterol levels to normal. The decrease in cholesterol levels in test animals is likely due to the presence of probiotic bacteria contained in fermented milk. According to Naim (2011), the mechanism of cholesterol reduction by lactic acid bacteria is through the secretion of bile salt hydolase (BSH) enzyme.

This will result in the deconjugation of bile acids, resulting the substance becoming difficult to be reabsorbed through the enterohepatic cycle and more bile acids are excreted through faeces. This condition will result in increased cholesterol needs in the body and eventually cholesterol levels in the blood will decrease. Other studies have shown that cholesterol reduction occurs due to the ability of probiotic bacteria that can reduce cholesterol levels in the blood by absorbing some cholesterol into the cells. 
Probiotic bacteria cells contain phospholipid bilayers that are able to attract cholesterol into the cells. Probiotic bacteria produce a cholesterol dehydrogenase cofactor that functions to activate the cholesterol reductase enzyme to convert cholesterol into coprostanol.

Coprostanol is a sterol that cannot be absorbed by the intestine and excreted through feces allowing cholesterol to go down (Ooi and Liong, 2010). The results of this study showed that the addition of fermented milk has antihypercholesterolemia activity which can influence in reducing cholesterol levels in male white rats induced by quail yolk.

\section{CONCLUSION}

The conclusion of this study is that the addition of probiotics from lactic acid bacteria in the fermented milk has been proved to reduce cholesterol levels in the blood of males wistar rats with an average percentage reduction in cholesterol by approximately $33.31 \%$.

\section{REFERENCES}

Burton, E., Arief, I. I., \& Taufik, E. (2014). Formulasi yoghurt probiotik karbonasi dan potensi sifat fungsionalnya. Jurnal Ilmu Produksi Dan Teknologi Hasil Peternakan, 2(1), 213-218. https://doi. org/10.29244/JIPTHP.2.1.213-218

Đokić, B., Đonović, N., Tadić, B., \& Nikolić, D. (2015). Factors and estimation of risk for cardiovascular diseases among patients in primary health care in Central Serbia. Central European Journal of Public Health, 23(3), 195-199. https://doi.org/10.21 101/cejph.a4009

Farinde, E., Obatolu, V., Oyarekua, M., Adeniran, H., Ejoh S.I, \& Olanipekun O.T. (2010). Physical and microbial properties of fruit flavoured fermented cowmilk and soy milk (yoghurt-like) under different temperature of storage. African Journal of Food Science and Technology, 1(5), 120-127.

Gulzar, N., Muqaddas Saleem, I., Rafiq, S., \& Nadeem, M. (2019). Therapeutic Potential of Probiotics and Prebiotics. In Microbial Health - Role of Prebiotics and Probiotics [Working Title]. IntechOpen. https://doi.org/10. 5772/intechopen.86762

Harini, M. (2009). Kadar Kolesterol Darah dan Ekspresi VCAM -1 Pada Endotel Aorta Tikus Putih (Rattus norvegicus L) Hiperkolesterolemik Setelah Perlakuan VCO. Surakarta: Universitas Sebelas Maret.

Ishmayana, S., Juanda, A., Suprijana, O., Djajasoepena, S., Idar, I., \& Rachman, S. D. (2015). Pengaruh konsumsi yogurt yang dibuat dengan kultur dua bakteri (Sterptococcus thermophillus dan Lactobacillus bulgaricus) dan tiga bakteri (Sterptococcus thermophillus, Lactobacillus bulgaricus dan Lactobacillus acidophilus) terhadap kadar kolesterol serum darah tikus. Chimica et Natura Acta, 3(3), 94-99. https://doi.org/10.24198/cna.v3.n3.9302

Kementerian Kesehatan Republik Indonesia. (2017). Penyakit Jantung Penyebab Kematian Tertinggi, Kemenkes Ingatkan CERDIK.

Manea, Iuliana, \& Buruleanu, L. (2010). Study of The Effects Shown by The Action of Various Microorganisms on The Lactic Fermentation of Juices. Romania: Valahia University of Targoviste.

Naim, H. Y. (2011). Pengaruh Pemberian Yoghurt Kedelai Hitam (Black Soyghurt) terhadap Profil Lipid Serum. Artikel Karya Tulis Ilmiah. Semarang: Universitas Diponegoro. 
Nielsen, S. (2003). Food Analysis (3rd ed.). New York: Kluwer Academic/ Plenum Publishers.

Octavia, Z. F., Djamiatun, K., \& Suci, N. (2017). Pengaruh pemberian yogurt sinbiotik tepung pisang tanduk terhadap profil lipid tikus sindrom metabolik. Jurnal Gizi Klinik Indonesia, 13(4), 159-169. https://doi .org/10.22146/ijen.19369

Ooi, L.-G., \& Liong, M.-T. (2010). Cholesterol-lowering effects of probiotics and prebiotics: a review of in vivo and in vitro findings. International Journal of Molecular Sciences, 11(6), 2499-2522. https:// doi.org/10.3390/ijms11062499

Pelezar, M., \& Chan, E. C. (2007). DasarDasar Mikrobiologi. (R. Hadioetomo, T. Imas, S. Tjitrosomo, \& S. Angka, Eds.) (1st ed.). Jakarta: Indonesia Press.

Pisano, M., Viale, S., Conti, S., Fadda, M., Deplano, M., Melis, M. P., Cosentino, S. (2014). Preliminary Evaluation of Probiotic Properties of Lactobacillus Strains Isolated from Sardinian Dairy Products. Biomed Research International.

Puryana, I. G. P. S. (2011). Populasi Lactobacillus rhamnosus SKG 34 dalam Saluran Pencernaan dan Pengaruhnya Terhadap Kadar Kolesterol Tikus Putih (Rattus norvegicus). Bali: Universitas Udayana.

Resnawati, H. (2010). Kualitas Susu pada Berbagai Pengolahan dan Penyimpanan. Semiloka Nasional Prospek Industri Sapi Perah Menuju Perdagangan Bebas. Bogor: Balai Penelitian Ternak.

Sadler, G., \& Murphy, P. (2003). pH and Titratable Acidity. In S. Nielsen (Ed.), Food Analysis (3rd ed.). India: Purdue
University.

Sawitri, M., Manab, A., \& Palupi, T. W. (2008). The study on gelatine addition to acidity, ph, water holding capacity and syneresis of yogurt. Jurnal Ilmu Dan Teknologi Hasil Ternak, 3(1), 35-42.

Septiani, A. H., Kusrahayu, K., \& Legowo, A. M. (2013). Pengaruh penambahan susu skim pada proses pembuatan frozen yogurt yang berbahan dasar whey terhadap total asam, $\mathrm{pH}$ dan jumlah bakteri asam laktat. Animal Agriculture Journal, 2(1), 225-231.

Setiawan, D. I., Tjahyono, K., \& Afifah, D. N. (2016). Pemberian kecambah kacang kedelai terhadap kadar malondialdehid (MDA) dan superoxide dismutase (SOD) tikus Sprague Dawley hiperkolesterolemia. Jurnal Gizi Klinik Indonesia, 13(1), 20-26. https://doi.org/ 10.22146/ijen.2 2815

Sintasari, R. A., Kusnadi, J., \& Ningtyas, D. W. (2013). Pengaruh penambahan konsentrasi susu skim dan sukrosa terhadap karakterisik minuman probiotik sari beras merah. Jurnal Pangan Dan Agroindustri, 2(3), 65-75.

Sunarlim, R., Setiyanto, H., \& Poeloengan, M. (2007). Pengaruh Kombinasi Starter Bakteri Lactobacillus bulgaricus, Streptococcus thermophilus, dan Lactobacillus plantarum Terhadap Sifat Mutu Susu Fermantasi. Seminar Nasional Teknologi Peternakan dan Veteriner.

Syachroni. (2014). Pengaruh Kombinasi Starter Kultur Lactobacillus plantarum Lactobacillus acidophillus Terhadap Karakteristik Mikrobiologis dan Kimiawi Pada Minuman Fermentasi. Makasar: Universitas Hasanuddin. 
Wang, L., Guo, M.-J., Gao, Q., Yang, J.-F., Yang, L., Pang, X.-L., \& Jiang, X.-J. (2018). The effects of probiotics on total cholesterol. Medicine, 97(5), e9679. https://doi.org/10.1097/MD.00 00000000009679
Yunus, Y., \& Zubaidah, E. (2014). Pengaruh konsentrasi sukrosa dan lama fermentasi terhadap viabilitas 1 . casei selama penyimpanan beku velva pisang ambon. Jurnal Pangan Dan Agroindustri, 3(2), 303-312. 